\title{
FAKTOR-FAKTOR YANG BERHUBUNGAN DENGAN KONDISI SUHU DAN KELEMBABAN RUANG KELUARGA DI DUSUN KOTAYASA DESA KOTAYASA KECAMATAN SUMBANG KABUPATEN BANYUMAS TAHUN 2016
}

\author{
Dian Ernawati $^{*}$, Asep Tata Gunawan ${ }^{*}$, Zaeni Budiono ${ }^{*}$ ) \\ Jurusan Kesehatan Lingkungan, Politeknik Kesehatan Kemenkes Semarang, \\ Jl.Raya Baturraden KM 12 Purwokerto
}

\begin{abstract}
Abstrak
Ruang keluarga harus sehat dan nyaman agar penghuninya dapat berkarya untuk meningkatkan produktifitas. Kondisi fisik lingkungan ruang keluarga yang tidak memenuhi syarat dapat menyebabkan gangguan penyakit. Data jenis penyakit tahun 2015 di wilayah Puskesmas II Sumbang menunjukkan jumlah penderita yang tertinggi adalah penyakit ISPA (4.183 orang), terbanyak berada di Desa Kotayasa (1.151 orang).

Penelitian bertujuan untuk mengetahui adanya faktor-faktor yang berhubungan dengan kondisi suhu dan kelembaban ruang keluarga di Dusun Kotayasa, Desa Kotayasa, kecamatan Sumbang, Kabupaten Banyumas.

Jenis penelitian adalah observasional dengan pendekatan cross sectional. Metode pengumpulan data menggunakan wawancara, observasi langsung, pengukuran dan perhitungan.

Kondisi suhu ruang keluarga yang memenuhi syarat 68,9\%,yang tidak memenuhi 31,1\%. Kondisi kelembaban yang memenuhi syarat 54,4\%, yang tidak memenuhi 45,6\%. Ada hubungan yang bermakna antara jenis lantai dengan suhu dan kelembaban, luas ventilasi dengan suhu tidak ada hubungan sedangkan dengan kelembaban ada hubungan, pencahayaan dengan suhu dan kelembaban tidak ada hubungan, ada hubungan jenis dinding dengan suhu dan kelembaban, kepadatan penghuni tidak ada hubungan yang bermakna dengan suhu dan kelembaban. Kata kunci:suhu dan kelembaban
\end{abstract}

\begin{abstract}
The family room must be healthy and comfortable, so that occupants can work for increase productivity. The physical condition of residential neighborhood such as ventilation, occupant density, temperature, humidity are not eligible can cause disease. Data types of the disease in 2015 in the area of Public Health Center II Sumbang shows the highest number of people with the disease is ISPA (4,183 patients), most located in the Kotayasa Village (1,151 patients). This research aimed to know associated factors with family room temperature and humidity in Kotayasa Village Sumbang Subdistrict Banyumas Regency.

The research was observational with cross sectional approach. Methods of data collection using interviews, direct observations, measurements and calculations.

Family room temperature conditions qualified $69,8 \%$, qualified $31.1 \%$. Humidity conditions qualified $54.4 \%$, not qualified $45.6 \%$. There was significant association between the type of floor with the temperature and humidity, ventilation with temperature was not significant, while the humidity was significant, lighting with temperature and humidity are not significant, types of walls with temperature and humidity, occupant density have no significant relationship with temperature and humidity.
\end{abstract}

Keywords : : Temperature and humidity

\footnotetext{
*) E-mail: dianernawatiaffan@yahoo.co.id

${ }^{* *}$ E-mail: aseptatagunawan@yahoo.co.id

***) E-mail: pakzaeni@gmail.com
} 


\section{Pendahuluan}

Pembangunan kesehatan sebagai modal dasar pembangunan yang dirumuskan dalam Indonesia sehat 2015. Dengan adanya kebijakan tersebut diharapkan masyarakat Indonesia akan mempunyai kesadaran, kemauan dan kemampuan untuk hidup sehat sehingga dapat terwujud derajat kesehatan yang optimal (Depkes RI, 2014, h.4).

Data jenis penyakit tahun 2015 menunjukkan bahwa secara berurutan jumlah penderita di wilayah Puskesmas II Sumbang adalah yang tertinggi penyakit ISPA 4.183 penderita, dan terendah scabies dengan jumlah penderita 241 penderita. (Laporan Penyakit Puskesmas II Sumbang tahun 2015).

Desa Kotayasa merupakan salah satu desa di wilayah kerja Puskesmas II Sumbang yang tingkatan angka ISPA tertinggi pada tahun 2015 dibandingkan desa yang lain, yaitu sebesar 1.151 penderita. Desa Kotayasa terbagi menjadi wilayah Dusun yaitu : 1). Dusun Kotayasa, wilayahnya RW I, RW II, RW III 2). Dusun Glempang, wilayahnya RW V 3). Dusun Genting, wilayahnya Rw IV, RW VI. Dengan jumlah penderita ISPA terbanyak di wilayah Dusun Kotayasa.

Dusun Kotayasa juga merupakan dusun dengan suhu yang cukup tinggi dan kelembaban yang cukup tinggi; suhu berkisar $20^{0} \mathrm{C}-32^{0} \mathrm{C}$ dan kelembaban $53 \%$ - 68\%. Sebagian penduduk Dusun Kotayasa tinggal pada perumahan yang permanen dan semi permanen sehingga berperan penting terhadap kondisi suhu dan kelembaban di ruangan dalam rumah termasuk ruang keluarga. Ruang keluarga merupakan salah satu bagian dari rumah yang merupakan salah satu persyaratan pokok bagi kehidupan manusia di samping sandang, pangan dan papan. Selain itu ruang keluarga juga harus sehat agar penghuninya dapat bekerja secara produktif. Konstruksi dan lingkungan ruang keluarga juga harus diperhatikan dengan baik. Ruang keluarga yang sehat juga harus memenuhi kebutuhan fisiologis dan psikologis. Kebutuhan akan jenis lantai yang kedap air, ventilasi yang memenuhi syarat untuk terjadinya sirkulasi udara dalam ruang keluarga, pencahayaan ruang keluarga yang optimal, bahan dan struktur dinding yang kedap air, dan tersedianya ruang keluarga yang optimal untuk aktivitas anggota keluarga sangat diperlukan. Faktor-faktor tersebut mempunyai peranan yang penting terhadap kondisi suhu dan kelembaban ruang keluarga yang optimal. Dimana kondisi suhu dan kelembaban ruang keluarga yang optimal sangat penting untuk kenyamanan dan kesehatan setiap anggota keluarga.

Hipotesis dalam penelitian ini adalah hipotesis nol, yaitu tidak ada faktor-faktor yang berhubungan dengan kondisi suhu dan kelembaban ruang keluarga di Dusun Kotayasa, Desa Kotayasa, Kecamatan Sumbang, Kabupaten Banyumas.

Tujuan penelitian adalah mengetahui adanya faktor-faktor yang berhubungan dengan kondisi suhu dan kelembaban ruang keluarga di dusun Kotaysa, desa Kotayasa, Kecamatan Sumbang, Kabupaten Banyumas.

\section{Bahan dan Metode}

Jenis penelitian ini adalah bersifat observasional dengan pendekatan cross sectional. Populasi dalam penelitian ini adalah semua rumah yang ada di dusun Kotayasa, desa Kotayasa, Kecamatan Sumbang, Kabupaten Banyumas, yang wilayahnya terdiri dari RW I, RW II, dan RW III sebanyak 1.295 rumah. Cara pengambilan sampel menurut wilayah RW di dusun Kotayasa teknik pengambilan dengan cara simpel random sampling Besar sampel dapat dihitung berdasarkan proporsi kejadian. Jadi sampel yangg diambil sebanyak 90 rumah.

Alat yang digunakan mengumpulkan data adalah Checklist untuk mengamati jenis lantai dan jenis dinding dan kuesioner ke rumah-rumah penduduk terutama untuk mengetahui tingkat

kepadatan penghuni, sedangkan alat ukurnya menggunakan Termohygrometer Digital untuk mengukur suhu dan kelembaban, Luxmeter untuk mengukur pencahayaan, Rollmeter untuk mengukur luas lantai dan luas ventilasi.

Analisis data dalam penelitian ini dengan menggunakan analisis inferersial (uji hipotesis) dengan pendekatan cross section.

\section{Hasil dan Pembahasan}

\section{Univariat}

Jenis Lantai

Tabel 4.2 Distribusi Frekuensi Variabel Jenis Lantai

\begin{tabular}{lll}
\hline Jenis Lantai & Frekuensi & $\%$ \\
\hline Tidak Memenuhi & & 20.0 \\
Syarat & 18 & 80.0 \\
Memenuhi Syarat & 72 & 100,0 \\
\hline Jumlah & 90 & \\
\hline
\end{tabular}

Berdasarkan data pada Tabel 4.2 dapat diketahui bahwa mayoritas jenis lantai pada ruang keluarga responden memenuhi syarat, yaitu sebanyak 72 ruang keluarga atau $80 \%$, yaitu berjenis plester/ ubin/keramik, bersih, kedap air, dan tidak retak. Sementara 18 ruang keluarga atau $20 \%$ yang tidak memenuhi syarat disebabkan minimal salah satu persyaratan tersebut tidak terpenuhi, misalnya ada yang lantainya berupa tanah, retak, dan kotor.

\section{Luas Ventilasi}

Tabel 4.5 Distribusi Frekuensi Variabel Luas Ventilasi

\begin{tabular}{lll}
\hline Luas Ventilasi & Frekuensi & $\%$ \\
\hline Tidak Memenuhi & 26 & 28,9 \\
Syarat & 64 & 71,1 \\
Memenuhi Syarat & 90 & 100,0 \\
\hline Jumlah & 90 \\
\hline
\end{tabular}


Berdasarkan data pada Tabel 4.5 dapat diketahui bahwa $28,9 \%$ luas ventilasi ruang keluarga responden tidak memenuhi syarat dan $71,1 \%$ memenuhi syarat.

\section{Pencahayaan}

Tabel 4.6 Distribusi Frekuensi Variabel Pencahayaan

\begin{tabular}{lll}
\hline Pencahayaan & Frekuensi & $\%$ \\
\hline Tidak Memenuhi & 27 & 30 \\
Syarat & 63 & 70 \\
Memenuhi Syarat & 63 & 100,0 \\
\hline Jumlah & 90 &
\end{tabular}

Berdasarkan data pada Tabel 4.6 dapat diketahui bahwa ruang keluarga responden yang tidak memenuhi syarat $30 \%$ dan yang memenuhi syarat 70 $\%$.

\section{Jenis Dinding}

Tabel 4.8

Distribusi Frekuensi Variabel Jenis

Dinding

\begin{tabular}{lll}
\hline Jenis Dinding & Frekuensi & $\%$ \\
\hline Tidak Memenuhi & 40 & 44,4 \\
Syarat & 50 & 55,6 \\
Memenuhi Syarat & 90 & 100,0 \\
\hline Jumlah & 5
\end{tabular}

Berdasarkan data pada Tabel 4.8 dapat diketahui bahwa 40 responden atau $44,4 \%$ tidak memenuhi syarat yaitu ruang keluarga yang jenis dindingnya tidak permanen dan 50 responden ataau $55,6 \%$ memenuhi syarat yaitu ruang keluarga yang jenis dindingnya permanen dan semi permanen.

\section{Kepadatan Penghuni}

Tabel 4.10 Distribusi Frekuensi Variabel Kepadatan Penghuni

\begin{tabular}{lll}
\hline Kepadatan Penghuni & Frekuensi & $\%$ \\
\hline Tidak Memenuhi Syarat & 83 & 92.2 \\
Memenuhi Syarat & 7 & 7.8 \\
\hline Jumlah & 90 & 100,0 \\
\hline
\end{tabular}

Berdasarkan data pada tabel 4.10 dapat diketahui bahwa hanya sebanyak 7 responden atau 7,8\% yang memenuhi syarat dan 83 responden atau 92,2\% tidak memenuhi syarat. Jadi tingkat kepadatan penghuni pada rumah responden termasuk tinggi.

Suhu

Tabel 4.11 Distribusi Frekuensi Variabel Suhu

\begin{tabular}{lll}
\hline Suhu & Frekuensi & $\%$ \\
\hline Tidak Memenuhi & 28 & 31,1 \\
Syarat & 62 & 68,9 \\
Memenuhi Syarat & 62 & 100,0 \\
\hline Jumlah & 90 &
\end{tabular}

Berdasarkan data pada Tabel 4.11 dapat diketahui bahwa sebanyak 28 responden atau $31,1 \%$ suhunya tidak memenuhi syarat dan 62 responden atau $69,8 \%$ suhunya memenuhi syarat.

\section{Kelembaban}

Tabel 4.12 Distribusi Frekuensi Variabel Kelembaban

\begin{tabular}{lll}
\hline Kelembaban & Frekuensi & $\%$ \\
\hline Tidak Memenuhi & 41 & 45.6 \\
Syarat & 49 & 54.4 \\
Memenuhi Syarat & 49 & 100,0 \\
\hline Jumlah & 90 &
\end{tabular}

Berdasarkan data pada Tabel 4.12 dapat diketahui bahwa sebanyak 41 responden atau $45,6 \%$ kelembabannya tidak memenuhi syarat dan 49 responden atau 54,4\% kelembabannya memenuhi syarat. Ruang keluarga responden yang mempunyai tingkat kelembaban memenuhi syarat yaitu antara $40 \%$ s.d $60 \%$.

\section{Bivariat}

Hubungan Antara Variabel Jenis Lantai Dengan Suhu

Tabel 4.13 Tabulasi Silang Hubungan antara Jenis Lantai dengan Suhu

\begin{tabular}{|c|c|c|c|c|c|c|}
\hline \multirow{3}{*}{$\begin{array}{l}\text { Jenis } \\
\text { Lantai }\end{array}$} & \multicolumn{4}{|c|}{ Suhu } & \multirow{2}{*}{\multicolumn{2}{|c|}{ Total }} \\
\hline & \multicolumn{2}{|c|}{$\begin{array}{l}\text { Tidak } \\
\text { Memenuh } \\
\text { i Syarat }\end{array}$} & \multicolumn{2}{|c|}{$\begin{array}{l}\text { Memenuhi } \\
\text { Syarat }\end{array}$} & & \\
\hline & $\mathrm{f}$ & $\%$ & $\mathrm{f}$ & $\%$ & $\mathrm{f}$ & $\%$ \\
\hline \multicolumn{7}{|l|}{ Tidak } \\
\hline $\begin{array}{l}\text { Memenuhi } \\
\text { Syarat }\end{array}$ & 1 & 5,6 & 17 & 94,4 & 18 & 100 \\
\hline $\begin{array}{l}\text { Memenuh } \\
\text { i Syarat }\end{array}$ & 27 & 37,5 & 45 & 62,5 & 72 & 100 \\
\hline Total & 28 & 31,1 & 62 & 68,9 & 90 & 100 \\
\hline \multicolumn{3}{|l|}{$\mathrm{p}$ value $=$} & \multicolumn{4}{|c|}{276} \\
\hline
\end{tabular}

Hasil analisis statistik Chi Square untuk hubungan antara luas lantai dengan kondisi suhu menunjukkan nilai $p$ sebesar 0,020 . Karena nilai p lebih kecil dari 0,05 maka hubungan antara jenis lantai dengan kondisi suhu dinyatakan signifikan. Koefisien phi menunjukkan angka sebesar 0,276 yang berarti kekuatan hubungannya lemah.

\begin{tabular}{|c|c|c|c|c|c|c|}
\hline \multirow{3}{*}{$\begin{array}{l}\text { Luas } \\
\text { Ventilasi }\end{array}$} & \multicolumn{4}{|c|}{ Suhu } & \multirow{2}{*}{\multicolumn{2}{|c|}{ Total }} \\
\hline & \multicolumn{2}{|c|}{$\begin{array}{l}\text { Tidak } \\
\text { Memenuhi } \\
\text { Syarat }\end{array}$} & \multicolumn{2}{|c|}{$\begin{array}{l}\text { Memenuhi } \\
\text { Syarat }\end{array}$} & & \\
\hline & $\mathrm{f}$ & $\%$ & $\mathrm{f}$ & $\%$ & $\mathrm{f}$ & $\%$ \\
\hline $\begin{array}{l}\text { Tidak } \\
\text { Memenuhi } \\
\text { Syarat } \\
\text { Memenuhi }\end{array}$ & 4 & 15,4 & 22 & 84,6 & 26 & 100 \\
\hline Syarat & 24 & 37,5 & 40 & 62,5 & 64 & 100 \\
\hline Total & 28 & 31,1 & 62 & 68,9 & 90 & 100 \\
\hline \multicolumn{3}{|c|}{$\mathrm{p}$ value $=0,071$} & \multicolumn{4}{|c|}{ phi $=0,217$} \\
\hline
\end{tabular}

Hubungan antara Luas Ventilasi dengan Suhu

Tabel 4.14 Tabulasi Silang Hubungan antar Luas Ventilasi dengan Suhu

Hasil analisis statistik untuk hubungan antara luas ventilasi dengan kondisi suhu menunjukkan nilai $\mathrm{p}$ sebesar 0,071. Karena nilai p lebih besar dari 0,05 maka hubungan antara luas ventilasi dengan kondisi suhu dinyatakan tidak signifikan. Koefisien phi menunjukkan angka sebesar 0,217. 
Hubungan antara Pencahayaan dengan Suhu Tabel 4.15 Tabulasi Silang Hubungan antara Pencahayaan dengan Suhu

\begin{tabular}{|c|c|c|c|}
\hline \multirow{3}{*}{$\begin{array}{l}\text { Pencahaya } \\
\text { an }\end{array}$} & \multicolumn{2}{|l|}{ Suhu } & \multirow[b]{2}{*}{ Total } \\
\hline & $\begin{array}{l}\text { Tidak } \\
\text { Memenu } \\
\text { hi Syarat }\end{array}$ & $\begin{array}{l}\text { Memenu } \\
\text { hi Syarat }\end{array}$ & \\
\hline & $\mathrm{f} \quad \%$ & $\%$ & $\%$ \\
\hline
\end{tabular}

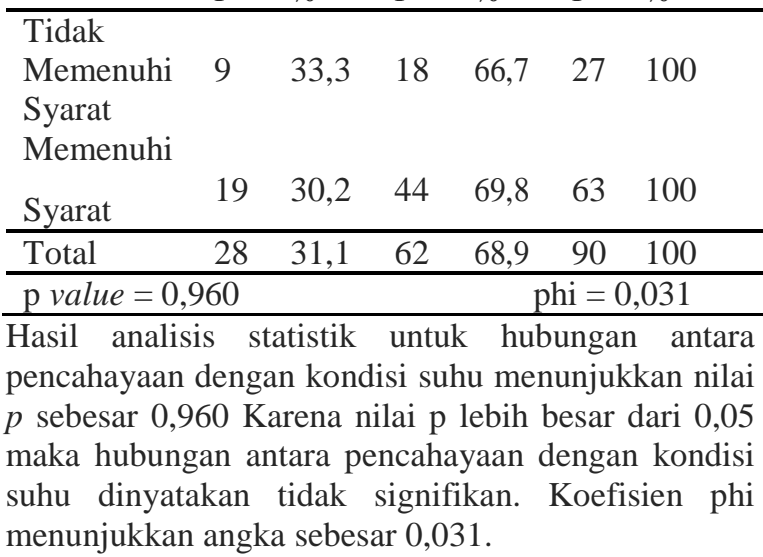

Hubungan antara Jenis Dinding dengan Suhu

Tabel 4.16 Tabulasi Silang Hubungan antara Jenis Dinding dengan Suhu

\begin{tabular}{|c|c|c|c|c|c|c|}
\hline \multirow{3}{*}{$\begin{array}{l}\text { Jenis } \\
\text { Dinding }\end{array}$} & \multicolumn{4}{|c|}{ Suhu } & \multirow{2}{*}{\multicolumn{2}{|c|}{ Total }} \\
\hline & \multicolumn{2}{|c|}{$\begin{array}{l}\text { Tidak } \\
\text { Memenuhi } \\
\text { Syarat }\end{array}$} & \multicolumn{2}{|c|}{$\begin{array}{l}\text { Memenu } \\
\text { hi Syarat }\end{array}$} & & \\
\hline & $f$ & $\%$ & $\mathrm{f}$ & $\%$ & $\mathrm{f}$ & $\%$ \\
\hline \multicolumn{7}{|l|}{ Tidak } \\
\hline $\begin{array}{l}\text { Memenuhi } \\
\text { Syarat }\end{array}$ & 5 & $\begin{array}{l}12 \\
, 5\end{array}$ & 35 & 87,5 & 40 & $\begin{array}{l}10 \\
0\end{array}$ \\
\hline Memenuhi & & 46 & & & & 10 \\
\hline Syarat & 23 & ,0 & 27 & 54,0 & 50 & 0 \\
\hline Total & 28 & $\begin{array}{l}31 \\
1\end{array}$ & 62 & 68,9 & 90 & $\begin{array}{l}10 \\
0\end{array}$ \\
\hline \multicolumn{3}{|l|}{$\mathrm{p}$ value $=0,001$} & \multicolumn{4}{|c|}{ phi $=0.360$} \\
\hline \multicolumn{7}{|c|}{$\begin{array}{l}\text { Hasil analisis statistik untuk hubungan antara } \\
\text { pencahayaan dengan kondisi suhu menunjukkan nilai } \\
p \text { sebesar 0,001. Karena nilai p lebih kecil dari } 0,05 \\
\text { maka hubungan antara jenis dinding dengan kondisi } \\
\text { suhu dinyatakan signifikan. Koefisien phi } \\
\text { menunjukkan angka sebesar } 0,360 \text { yang berarti } \\
\text { kekuatan hubungannya lemah. } \\
\text { Hubungan antara Kepadatan Penghuni dengan } \\
\text { Suhu } \\
\text { Tabel } 4.17 \text { Tabulasi Silang Hubungan antara } \\
\text { Kepadatan Penghuni dengan Suhu }\end{array}$} \\
\hline \multirow[t]{2}{*}{$\begin{array}{l}\text { Kepadatan } \\
\text { Penghuni }\end{array}$} & $\begin{array}{l}\text { Suh } \\
\text { Tida } \\
\text { Mer } \\
\text { i Sy }\end{array}$ & renuh & & $\begin{array}{l}\text { enuh } \\
\text { rat }\end{array}$ & \multicolumn{2}{|c|}{ Total } \\
\hline & $\mathrm{f}$ & $\%$ & $\mathrm{f}$ & $\%$ & $\mathrm{f}$ & $\%$ \\
\hline $\begin{array}{l}\text { Tidak Memenuhi } \\
\text { Syarat }\end{array}$ & 27 & 32,5 & 56 & 67,5 & 83 & 100 \\
\hline $\begin{array}{l}\text { Memenuhi } \\
\text { Syarat }\end{array}$ & 1 & 14,3 & 6 & 85,7 & 7 & 100 \\
\hline Total & 28 & 31,1 & 62 & 68,9 & 90 & 100 \\
\hline $\mathrm{p}$ value $=0,564$ & & & & $=0,106$ & & \\
\hline
\end{tabular}

Hasil analisis statistik untuk hubungan antara kepadatan penghuni dengan kondisi suhu menunjukkan nilai $p$ sebesar 0,428 . Karena nilai $p$ lebih besar dari 0,05 maka hubungan antara kepadatan penghuni dengan kondisi suhu dinyatakan tidak signifikan. Koefisien phi menunjukkan angka sebesar 0,106 .

Analisis Hubungan Antara Variabel Jenis Lantai Dengan Kelembaban

Tabel 4.18 Tabulasi Silang Hubungan antara Jenis Lantai Dengan Kelembaban

\begin{tabular}{|c|c|c|c|c|c|c|}
\hline \multirow{3}{*}{$\begin{array}{l}\text { Jenis } \\
\text { Lantai }\end{array}$} & \multicolumn{4}{|c|}{ Kelembaban } & \multirow{2}{*}{\multicolumn{2}{|c|}{ Total }} \\
\hline & \multicolumn{2}{|c|}{$\begin{array}{l}\text { Tidak } \\
\text { Memenuhi } \\
\text { Syarat }\end{array}$} & \multicolumn{2}{|c|}{$\begin{array}{l}\text { Memenu } \\
\text { hi Syarat }\end{array}$} & & \\
\hline & $\mathrm{f}$ & $\%$ & $\mathrm{f}$ & $\%$ & $f$ & $\%$ \\
\hline $\begin{array}{l}\text { Tidak } \\
\text { Memenuhi } \\
\text { Syarat } \\
\text { Memenuhi }\end{array}$ & 13 & 72,2 & 5 & 27,8 & 18 & 100 \\
\hline Syarat & 28 & 38,9 & 44 & 61,1 & 72 & 100 \\
\hline Total & 41 & 45,6 & 49 & 54,4 & 90 & 100 \\
\hline $\mathrm{p}$ value $=0$, & & & & phi & 0,2 & \\
\hline
\end{tabular}

Hasil analisis statistik untuk hubungan antara luas lantai dengan kelembaban menunjukkan nilai $p$ sebesar 0,023. Karena nilai p lebih kecil dari 0,05 maka hubungan antara luas lantai dengan kelembaban dinyatakan signifikan. Koefisien phi menunjukkan angka sebesar 0,268 yang berarti kekuatan hubungannya lemah.

Hubungan antara Luas Ventilasi dengan Kelembaban

Tabel 4.19 Tabulasi Silang Hubungan antara Luas Ventilasi dengan Kelembaban

\begin{tabular}{|c|c|c|c|c|c|c|}
\hline \multirow{3}{*}{$\begin{array}{l}\text { Luas } \\
\text { Ventilasi }\end{array}$} & \multicolumn{4}{|c|}{ Kelembaban } & \multirow{2}{*}{\multicolumn{2}{|c|}{ Total }} \\
\hline & \multicolumn{2}{|c|}{$\begin{array}{l}\text { Tidak } \\
\text { Memenuhi } \\
\text { Syarat }\end{array}$} & \multicolumn{2}{|c|}{$\begin{array}{l}\text { Memenu } \\
\text { hi Syarat }\end{array}$} & & \\
\hline & $\mathrm{f}$ & $\%$ & $\mathrm{f}$ & $\%$ & $\mathrm{f}$ & $\%$ \\
\hline $\begin{array}{l}\text { Tidak } \\
\text { Memenuhi } \\
\text { Syarat }\end{array}$ & 17 & 65,4 & 9 & 34,6 & 26 & 100 \\
\hline $\begin{array}{l}\text { Memenuhi } \\
\text { Syarat }\end{array}$ & 24 & 37,5 & 40 & 62,5 & 64 & 100 \\
\hline Total & 41 & 45,6 & 49 & 54,4 & 90 & 100 \\
\hline $\mathrm{p}$ value $=0$, & & & & phi & 0,2 & \\
\hline
\end{tabular}

Hasil analisis statistik untuk hubungan antara luas ventilasi dengan kelembaban menunjukkan nilai $p$ sebesar 0,030. Karena nilai p lebih kecil dari 0,05 maka hubungan antara luas ventilasi dengan kelembaban dinyatakan signifikan. Koefisien phi menunjukkan angka sebesar 0,254 yang berarti kekuatan hubungannya lemah.

Hubungan antara Pencahayaan dengan Kelembaban

Tabel 4.20 Tabulasi Silang Hubungan antara Pencahayaan dengan Kelembaban

Pencahayaan Kelembaban Total 


\begin{tabular}{|c|c|c|c|c|c|c|}
\hline & \multirow{2}{*}{\multicolumn{2}{|c|}{$\begin{array}{l}\text { Tidak } \\
\text { Memenu } \\
\text { hi Syarat } \\
\end{array}$}} & \multirow{2}{*}{\multicolumn{2}{|c|}{$\begin{array}{l}\text { Memenu } \\
\text { hi Syarat }\end{array}$}} & \multirow[b]{3}{*}{$\mathrm{f}$} & \multirow[b]{3}{*}{$\%$} \\
\hline & & & & & & \\
\hline & $\mathrm{f}$ & $\%$ & $\mathrm{f}$ & $\%$ & & \\
\hline $\begin{array}{l}\text { Tidak } \\
\text { Memenuhi } \\
\text { Syarat } \\
\text { Memenuhi }\end{array}$ & 11 & 40,7 & 16 & 59,3 & 27 & 100 \\
\hline Syarat & 30 & 47,6 & 33 & 52,4 & 63 & 100 \\
\hline Total & 41 & 45,6 & 49 & 54,4 & 90 & 100 \\
\hline \multicolumn{3}{|c|}{$\mathrm{p}$ value $=0,712$} & \multicolumn{4}{|c|}{ phi $=0,063$} \\
\hline \multicolumn{7}{|c|}{$\begin{array}{l}\text { Hasil analisis statistik untuk hubungan antara } \\
\text { pencahayaan dengan kelembaban menunjukkan nilai } \\
p \text { sebesar } 0,712 \text {. Karena nilai p lebih besar dari } 0,05 \\
\text { maka hubungan antara pencahayaan dengan } \\
\text { kelembaban dinyatakan tidak signifikan. Koefisien } \\
\text { phi menunjukkan angka sebesar } 0,063 \text {. }\end{array}$} \\
\hline
\end{tabular}

Hubungan antara Jenis Dinding dengan Kelembaban

Tabel 4.21 Tabulasi Silang Hubungan antara Jenis Dinding dengan Kelembaban

\begin{tabular}{|c|c|c|c|c|c|c|}
\hline \multirow{3}{*}{ Jenis Dinding } & \multicolumn{4}{|c|}{ Kelembaban } & \multirow{2}{*}{\multicolumn{2}{|c|}{ Total }} \\
\hline & \multicolumn{2}{|c|}{$\begin{array}{l}\text { Tidak } \\
\text { Memenu } \\
\text { hi Syarat }\end{array}$} & \multicolumn{2}{|c|}{$\begin{array}{l}\text { Memenu } \\
\text { hi Syarat }\end{array}$} & & \\
\hline & $\mathrm{f}$ & $\%$ & $\mathrm{f}$ & $\%$ & $\mathrm{f}$ & $\%$ \\
\hline $\begin{array}{l}\text { Tidak } \\
\text { Memenuhi } \\
\text { Syarat } \\
\text { Memenuhi }\end{array}$ & 28 & 70,0 & 12 & 30,0 & 40 & 100 \\
\hline Syarat & 13 & 26,0 & 37 & 74,0 & 50 & 100 \\
\hline Total & 41 & 45,6 & 49 & 54,4 & 90 & 100 \\
\hline $\mathrm{p}$ value $=0,000$ & & & & $\overline{h i}=0$ & 439 & \\
\hline
\end{tabular}

Hasil analisis statistik untuk hubungan antara jenis dinding dengan kelembaban menunjukkan nilai $p$ sebesar 0,000. Karena nilai p lebih kecil dari 0,05 maka hubungan antara jenis dinding dengan kelembaban dinyatakan signifikan. Koefisien phi menunjukkan angka sebesar 0,439 yang berarti kekuatan hubungannya lemah.

Hubungan antara Kepadatan Penghuni dengan Kelembaban

Tabel 4.22 Tabulasi Silang Hubungan antara Kepadatan Penghuni dengan Kelembaban

\begin{tabular}{|c|c|c|c|c|c|c|}
\hline \multirow{3}{*}{$\begin{array}{l}\text { Kepadatan } \\
\text { Penghuni }\end{array}$} & \multicolumn{4}{|c|}{ Kelembaban } & \multirow{2}{*}{\multicolumn{2}{|c|}{ Total }} \\
\hline & \multicolumn{2}{|c|}{$\begin{array}{l}\text { Tidak } \\
\text { Memenu } \\
\text { hi Syarat }\end{array}$} & \multicolumn{2}{|c|}{$\begin{array}{l}\text { Memenu } \\
\text { hi Syarat }\end{array}$} & & \\
\hline & $\mathrm{f}$ & $\%$ & $f$ & $\%$ & $f$ & $\%$ \\
\hline \multicolumn{7}{|l|}{ Tidak } \\
\hline $\begin{array}{l}\text { Memenuhi } \\
\text { Syarat }\end{array}$ & 36 & 43,3 & 47 & 56,6 & 83 & 100 \\
\hline $\begin{array}{l}\text { Memenuhi } \\
\text { Syarat }\end{array}$ & 5 & 71,4 & 2 & 28,6 & 7 & 100 \\
\hline Total & 41 & 45,6 & 49 & 54,4 & 90 & 100 \\
\hline \multicolumn{3}{|c|}{$\mathrm{p}$ value $=0,239$} & \multicolumn{4}{|c|}{ phi $=0,151$} \\
\hline
\end{tabular}

Hasil analisis statistik untuk hubungan antara kepadatan penghuni dengan kelembaban menunjukkan nilai $p$ sebesar 0,239. Karena nilai $\mathrm{p}$ lebih besar dari 0,05 maka hubungan antara kepadatan penghuni dengan kelembaban dinyatakan tidak signifikan. Koefisien phi menunjukkan angka sebesar 0,151.

\section{PEMBAHASAN}

\section{Hubungan Antara Variabel Jenis Lantai Dengan Suhu}

Berdasarkan hasil penelitian diketahui bahwa jenis lantai yang memenuhi syarat 72 ruang keluarga atau $80 \%$, yaitu lantai ruang keluarga berjenis plester/ubin/keramik, bersih, kedap air, dan tidak retak. Sementara ada 18 ruang keluarga atau $20 \%$ jenis lantai pada ruang keluarga responden tidak memenuhi syarat, karena tidak terpenuhinya minimal salah satu persyaratan, dimana ada yang lantainya masih berupa tanah, lantainya mengalami retak, dan kondisinya kotor.

Jenis lantai pada rumah responden $94,4 \%$ terbuat dari bahan yang kedap air. Secara keseluruhan jenis lantai sudah memenuhi syarat karena terbuat dari bahan keramik, ubin, dan plester. Hanya 5,6\% yang lantainya masih berupa tanah. Jenis lantai yang kedap air atau memenuhi syarat akan menaikkan suhu ruangan menjadi meningkat. Menurut Benyamin Lakitan (1994 h. 90) suhu tanah akan dipengaruhi oleh jumlah serapan radiasi matahari oleh permukaan bumi. Pada siang hari suhu permukaan tanah akan lebih tinggi dibandingkan suhu pada lapisan tanah yang lebih dalam. Hal ini disebabkan karena permukaan tanah yang akan menyerap radiasi matahari secara langsung pada siang hari tersebut, baru kemudian panas dirambatkan ke lapisan tanah yang lebih dalam secara konduksi. Sebaliknya pada malam hari permukaan tanah akan kehilangan panas terlebih dahulu, sebagai akibatnya suhu pada permukaan tanah akan lebih rendah dibandingkan dengan suhu pada tanah yang lebih dalam. Pada malam hari panas akan merambat dari lapisan tanah yang lebih dalam menuju ke permukaan.

Hasil penelitian menunjukkan bahwa jenis lantai mempunyai hubungan yang signifikan dengan kondisi suhu dengan $\mathrm{p}$ value $=0,02$, phi $=0,276$ dalam kategori hubungan lemah.

\section{Hubungan Antara Variabel Luas Ventilasi Dengan Suhu}

Berdasarkan hasil penelitian luas ventilasi ruang keluarga responden yang memenuhi syarat 64 rumah atau $71,1 \%$, sedangkan yang tidak memenuhi syarat 26 ruang keluarga atau $28,9 \%$.

Hasil penelitian menunjukkan bahwa luas ventilasi ruang keluarga responden sebagian besar memenuhi syarat, yaitu minimal $10 \%$ dari luas lantai. Menurut Winslow dan APHA (Heru Subaris Kasjono, 2011, h. 23-69) rumah yang sehat harus memenuhi beberapa persyaratan antara lain perhawaan (ventilasi) yang cukup untuk proses pergantian udara dalam ruangan, ukuran ventilasi yang memenuhi syarat yaitu $10 \%$ luas lantai. 
Ventilasi yang baik mendukung terwujudnya ruang keluarga yang sehat karena sirkulasi udara atau aliran udara melali lubang ventilasi di dalam

ruangan menjadi lebih lancar sehingga suhu menurun. Menurut Benyamin Lakitan (1994, h. 90-

92) panas dapat berpindah dari satu tempat ke tempat lain, yaitu dari tempat dengan suhu yang lebih tinggi ke tempat dengan suhu yang lebih rendah. Perpindahan panas pada udara dapat berlangsung karena pergerakan massa udara (konveksi).

Hasil penelitian menunjukkan bahwa luas ventilasi mempunyai hubungan yang signifikan dengan kondisi suhu dengan nilai $\mathrm{p}$ value sebesar 0,071 . Namun kekuatan hubungannya lemah karena nilai phi menunjukkan angka 0,217 untuk hubungan dengan suhu.

Untuk luas ventilasi yang sudah memenuhi syarat hendaknya dipertahankan kondisinya dan dianjurkan untuk membuka jendela pagi dan siang hari. Menurut Gunawan (Nur Ahmad Yusuf, 2005, h. 116) ventilasi adalah penyediaan udara segar ke dalam dan pengeluaran udara kotor dari suatu ruangan tertutup secara alamiah maupun mekanis. Tersedianya udara segar dalam rumah atau ruangan amat dibutuhkan manusia, sehingga apabila suatu ruangan tidak memiliki ventilasi yang baik dan over crowded maka akan menimbulkan keadaan yang dapat merugikan kesehatan.

\section{Hubungan Antara Variabel Pencahayaan Dengan} Suhu

\section{Berdasarkan hasil penelitian diketahui}

bahwa ruang keluarga responden yang pencahayaannya memenuhi syarat 63 ruang keluarga atau $70 \%$, sedangkan yang tidak memenuhi syarat 27 ruang keluarga atau $30 \%$.

Hasil penelitian menunjukkan bahwa $70 \%$ ruang keluarga responden memiliki pencahayaan yang memenuhi syarat, yaitu min 60 lux. 30\% ruang keluarga responden tidak memenuhi syarat karena pencahayaannya kurang dari 60lux. Pencahayaan yang memenuhi syarat terutama di siang hari yaitu pencahayaan yang berasal dari radiasi sinar matahari, terutama pada saat tengah hari yang akan menyebabkan kondisi suhu meningkat. Menurut Benyamin Lakitan (1994, h. 88) suhu udara akan berfluktuasi dengan nyata selama setiap periode 24 jam. Fluktuasi suhu udara berkaitan erat dengan proses pertukaran energi yang berlangsung di atmosfer. Pada siang hari sebagian dari radiasi matahari akan diserap oleh gas-gas atmosfer dan partikel-partikel padat yang melayang di atmosfer. Serapan energi radiasi matahari ini akan menyebabkan suhu udara meningkat. Suhu udara harian maksimum tercapai beberapa saat setelah intensitas cahaya maksimum tercapai. Intensitas cahaya maksimum tercapai pada saat berkas cahaya jatuh tegak lurus, yakni pada waktu tengah hari.

Pencahayaan yang memenuhi syarat akan berdampak positif terhadap kondisi suhu yang ideal guna mendukung kondisi rumah yang sehat. Menurut
Winslow dan APHA (Heru Subaris Kasjono, 2011, h. 23-69) rumah yang sehat harus memenuhi beberapa persyaratan antara lain pencahayaan yang cukup, baik cahaya alami maupun buatan.

Hasil penelitian menunjukkan bahwa pencahayaan mempunyai hubungan yang tidak signifikan dengan kondisi suhu dengan nilai $\mathrm{p}$ value sebesar 0,960. Kekuatan hubungannya dalam kategori lemah, dengan nilai phi 0,031.

\section{Hubungan Antara Variabel Jenis Dinding Dengan Suhu}

Berdasarkan hasil penelitian diketahui bahwa jenis dinding yang memenuhi syarat sebanyak 50 ruang keluarga atau $55,6 \%$, sedangkan yang tidak memenuhi syarat 40 ruang keluarga atau $44,4 \%$.

Hasil penelitian menunjukkan bahwa $55,6 \%$ jenis dinding ruang keluarga responden memenuhi syarat, yaitu permanen dan semi permanen. Jenis dinding ruang keluarga responden yang memenuhi syarat akan menurunkan keadaan atau kondisi suhu di dalam ruangan atau rumah responden. Menurut Benyamin Lakitan (1994 h.92) perpindahan panas pada medium padat, misalnya dinding hanya akan berlangsung secara konduksi secara konveksi tidak mungkin terjadi. Perambatan panas pada media padat mengikuti gradasi suhu

Menurut Suryanto (Vita Ayu Oktaviani, 2009, h. 17) dinding rumah yang baik menggunakan tembok, tetapi dinding rumah di daerah tropis khususnya di pedesaan banyak yangg berdinding papan, kayu, dan bambu. Hal ini disebabkan masyarakat pedesaan perekonomiannya kurang.

Hasil analisis statistik untuk hubungan antara jenis dinding dengan kondisi suhu menunjukkan adanya hubungan yang signifikan dengan nilai $\mathrm{p}$ sebesar 0,001. Kekuatan hubungannya dalam kategori lemah, dengan nilai phi 0,360 untuk hubungan dengan suhu.

\section{Hubungan Antara Variabel Kepadatan Penghuni Dengan Suhu}

Berdasarkan hasil penelitian diketahui bahwa kepadatan penghuni yang memenuhi syarat 7 rumah atau $7,8 \%$, sedangkan yang tidak memenuhi syarat 83 rumah atau $92,2 \%$.

Hasil penelitian menunjukkan bahwa sebagian besar rumah responden memiliki tingkat kepadatan yang tidak memenuhi syarat, yaitu $9 \mathrm{~m}^{2}$ /orang. Variabel kepadatan penghuni dihitung berdasarkan jumlah penghuni dibagi luas lantai. Jadi, tingkat kepadatan penghuni relatif tinggi, atau kondisi rumah responden $92,2 \%$ memiliki kepadatan yang tidak memenuhi syarat. Penulis juga menjumpai, dalam satu rumah ada kalanya dihuni oleh lebih dari 1 kk, misalnya jika ada anak yang sudah menikah tetapi masih tinggal serumah dengan orang tuanya. Hal ini khususnya dijumpai pada responden yang jumlah penghuni rumahnya di atas 5 orang.

Hasil analisis statistik menunjukkan bahwa hubungan antara kepadatan penghuni dengan kondisi 
suhu dinyatakan tidak signifikan karena nlai $p$ lebih besar dari 0,05 yaitu 0,428 untuk hubungan dengan suhu. Dengan nilai phi sebesar 0,106. Hal ini menunjukkan bahwa kepadatan penghuni tidak memberikan dampak yang berarti terhadap kondisi suhu pada rumah responden.

Kepadatan hunian rumah akan meningkatkan suhu ruangan yang disebabkan oleh pengeluaran panas badan. Dengan banyaknya penghuni maka kadar oksigen dalam ruangan menurun dan diikuti oleh peningkatan karbon dioksida atau $\mathrm{CO}^{2}$ di dalam ruangan atau rumah yang akan berdampak pada peningkatan suhu udara dalam ruangan atau rumah. Menurut Benyamin Lakitan (1994 h.147) sesungguhnya angin mempunyai fungsi lain yang sangat penting adalah dalam mencampur lapisan udara, antara udara panas dengan udara dingin, antara udara yang kaya karbon dioksida (CO2) dengan udara dengan kandungan karbon dioksida (CO2) yang lebih rendah.

Menurut Kemenkes RI (1999) luas ruangan tidur minimal $8 \mathrm{~m}^{2}$ dan tidak dianjurkan lebih dari 2 orang. Bangunan yang sempit dan tidak sesuai dengan jumlah penghuninya akan mempunyai dampak kurangnya oksigen dalam ruangan. Semakin padat penghuninya maka kebutuhan oksigen meningkat hal itu menyebabkan kondisi suhu rumah menjadi naik.

\section{Analisis Hubungan Antara Variabel Jenis Lantai} Dengan Kelembaban

Berdasarkan hasil penelitian diketahui bahwa jenis lantai yang memenuhi syarat 72 rumah atau $80 \%$, yaitu lantai ruang keluarga berjenis plester/ubin/keramik, bersih, kedap air, dan tidak retak. Sementara ada 18 ruang keluarga atau $20 \%$ jenis lantai pada ruang keluarga responden tidak memenuhi syarat, karena tidak terpenuhinya minimal salah satu persyaratan, dimana ada yang lantainya masih berupa tanah, lantainya mengalami retak, dan kondisinya kotor.

Jenis lantai pada ruang keluarga responden $94,4 \%$ terbuat dari bahan yang kedap air. Secara keseluruhan jenis lantai pada ruang keluarga responden sudah memenuhi syarat karena terbuat dari bahan keramik, ubin, dan plester. Hanya 5,6\% yang lantainya masih berupa tanah. Jenis lantai yang kedap air atau memenuhi syarat akan menurunkan kelembaban.

Hasil penelitian menunjukkan bahwa hubungan jenis lantai dengan kelembaban dengan nilai $\mathrm{p}$ value sebesar 0,023 menunjukkan adanya hubungan yang signifikan. Namun kategori hubungannya adalah lemah karena nilai phi adalah 0,268 untuk hubungan dengan kelembaban..

Lantai yang lembab terutama pada siang hari disebabkan oleh terjadinya proses penguapan air pada permukaan tanah yang akan meningkatkan kadar uap air sehingga meningkatkan kelembaban udara. Menurut Benyamin Lakitan (1994 h.110) kelembaban udara yang lebih tinggi pada udara dekat permukaan pada siang hari disebabkan karena penambahan uap air hasil evepotranspirasi dari permukaan. Proses ini berlangsung karena permukaan tanah menyerap radiasi matahari selama siang hari. Pada malam hari akan berlangsung proses kondensasi atau pengembunan yang memanfaatkan uap air yang berasal dari udara. Oleh sebab itu kandungan uap air di udara dekat permukaan akan berkurang.

\section{Hubungan Antara Variabel Luas Ventilasi Dengan Kelembaban}

Berdasarkan hasil penelitian luas ventilasi ruang keluarga responden yang memenuhi syarat 64 ruang keluarga atau $71,1 \%$, sedangkan yang tidak memenuhi syarat 26 ruang keluarga atau $28,9 \%$.

Hasil penelitian menunjukkan bahwa luas ventilasi ruang keluarga responden $71,1 \%$ memenuhi syarat, yaitu minimal $10 \%$ dari luas lantai. Ventilasi yang baik jelas mendukung terwujudnya ruang keluarga yang sehat karena sirkulasi udara menjadi lebih lancar. Menurut Winslow dan APHA (Heru Subaris Kasjono, 2011, h. 23-69) rumah yang sehat harus memenuhi beberapa persyaratan antara lain perhawaan (ventilasi) yang cukup untuk proses pergantian udara dalam ruangan. Ukuran ventilasi yang memenuhi syarat yaitu $10 \%$ luas lantai.

Hasil penelitian menunjukkan bahwa luas ventilasi mempunyai hubungan yang signifikan dengan kondisi kelembaban dengan nilai $\mathrm{p}$ value sebesar 0,030. Namun kekuatan hubungannya lemah karena nilai phi menunjukkan angka 0,254 untuk hubungan dengan kelembaban.

Menurut Gunawan (Nur Ahmad Yusuf, 2005, h. 116) ventilasi adalah penyediaan udara segar ke dalam dan pengeluaran udara kotor dari suatu ruangan tertutup secara alamiah maupun mekanis. Tersedianya udara segar dalam rumah atau ruangan amat dibutuhkan manusia, sehingga apabila suatu ruangan tidak memiliki ventilasi yang baik dan over crowded maka akan menimbulkan keadaan yang dapat merugikan kesehatan.

Ruang keluarga yang memenuhi syarat ventilasi yang baik diantaranya adalah berada di atas ketinggian jendela, dimana ketinggian jendela tidak lebih dari 2 meter, sehingga udara akan mudah masuk ke ruangan dan akan mempercepat proses percampuran udara. Menurut Benyamin Lakitan (1994 h. 110) kelembaban udara pada ketinggian lebih dari 2 meter dari permukaan tidak menunjukkan perbedaan yang nyata antara malam dan siang hari. Pada lapisan udara yang lebih tinggi tersebut, pengaruh udara menjadi lebih besar. Udara lembab dan udara kering dapat tercampur lebih cepat.

Menurut Benyamin Lakitan (1994 h.147) Sesungguhnya angin mempunyai fungsi lain yang sangat penting adalah dalam mencampur lapisan udara, antara udara panas dengan udara dingin, antara udara lembab dengan udara kering.

Hubungan Antara Variabel Pencahayaan Dengan Kelembaban 


\section{Berdasarkan hasil penelitian \\ diketahui}

bahwa ruang keluarga responden yang pencahayaannya memenuhi syarat 63 ruang keluarga atau $70 \%$, sedangkan yang tidak memenuhi syarat 27 ruang keluarga atau $30 \%$. Hasil penelitian menunjukkan bahwa $70 \%$ ruang keluarga responden memiliki pencahayaan yang memenuhi syarat, yaitu min 60 lux. 30\% ruang keluarga responden tidak memenuhi syarat karena pencahayaannya kurang dari 60lux.

Pada siang hari pencahayaan yang memenuhi syarat akan meningkatkan kondisi kelembaban dalam ruangan karena radiasi sinar matahari mengakibatkan kandungan uap air dalam ruangan meningkat. Menurut Benyamin Lakitan (1994, h. 108) dinamika kandungan uap air di atmosfer terutama disebabkan karena air dapat berubah dari cair ke gas atau sebaliknya dengan cepat. Kandungan uap air di udara akan meningkat, jika banyak air yang berubah dari bentuk cair ke gas. Proses ini dapat berlangsung jika ada masukan energi. Sumber energi utama yang dimanfaatkan dalam proses penguapan air ini adalah radiasi matahari.

Secara teoritis, pencahayaan berperan dalam mendukung rumah yang sehat. Pencahayaan yang memenuhi syarat akan berdampak positif terhadap kondisi kelembaban yang ideal guna mendukung kondisi rumah yang sehat. Menurut Winslow dan APHA (Heru Subaris Kasjono, 2011, h. 23-69) rumah yang sehat harus memenuhi beberapa persyaratan antara lain pencahayaan yang cukup, baik cahaya alam maupun buatan.

Hasil penelitian menunjukkan bahwa pencahayaan mempunyai hubungan yang tidak signifikan dengan kondisi kelembaban dengan nilai $\mathrm{p}$ value sebesar 0,712. Kekuatan hubungannya dalam kategori lemah, dengan nilai phi 0,063.

Pentingnya pencahayaan bagi ruang keluarga ditegaskan oleh Azrul Azwar (Nur Ahmad Yusuf, 2005, h. 117) bahwa penerangan ada dua macam, yaitu penerangan alami dan buatan. Penerangan alami sangat penting dalam menerangi rumah untuk mengurangi kelembaban. Penerangan alami diperoleh dengan masuknya sinar matahari ke dalam ruangan melalui jendela, celah maupun bagian lain dari rumah yang tebuka, selain berguna untuk penerangan sinar ini juga mengurangi kelembaban ruangan.

\section{Hubungan Antara Variabel Jenis Dinding Dengan Kelembaban}

Berdasarkan hasil penelitian diketahui bahwa jenis dinding yang memenuhi syarat sebanyak 50 ruang keluarga atau 55,6\%, sedangkan yang tidak memenuhi syarat 40 ruang keluarga atau 44,4\%.

Hasil penelitian menunjukkan bahwa jenis dinding ruang keluarga responden sebagian besar memenuhi syarat, yaitu permanen dan semi permanen. Hal ini menunjukkan ruang keluarga responden secara umum mendukung bagi terciptanya ruang keluarga yang sehat karena jenis dindingnya memenuhi syarat. Namun demikian perlu pula dicermati bahwa ruang keluarga yang belum permanen juga cukup banyak. ruang keluarga tersebut pada umumnya terbuat dari kayu atau papan. Jenis kayu yang digunakan kebanyakan bukan kayu yang mahal, seperti jati, melainkan kayu alba, kayu mahoni, dan jenis kayu lain yang harganya di bawah kayu jati. Menurut Benyamin Lakitan (1994, h. 107) laju penguapan ditentukan oleh perbedaan potensi air antara "sumber" dengan "sasaran". Potensi air adalah total energi bebas air pada suatu material, berupa larutan, bahan padat yang menyerap air, dan udara. Pada bahan padat (misalnya dinding) potensi air tergantung pada kekuatan yang mengikat molekul air pada bahan padat tersebut.

Menurut Suryanto (Vita Ayu Oktaviani, 2009 , h. 17) dinding rumah yang baik menggunakan tembok, tetapi dinding rumah di daerah tropis khususnya di pedesaan banyak yangg berdinding papan, kayu, dan bambu. Hal ini disebabkan masyarakat pedesaan perekonomiannya kurang.

Hasil analisis statistik untuk hubungan antara jenis dinding dengan kondisi kelembaban menunjukkan adanya hubungan yang signifikan dengan nilai $\mathrm{p}$ sebesar 0,000 . Kekuatan hubungannya dalam kategori lemah, dengan nilai phi 0,439 untuk hubungan dengan kelembaban. Hasil tersebut menunjukkan bahwa jenis dinding ikut memberikan kontribusi yang cukup penting terhadap terwujudnya rumah yang sehat.

\section{Hubungan Antara Variabel Kepadatan Penghuni Dengan Kelembaban}

Berdasarkan hasil penelitian diketahui bahwa kepadatan penghuni yang memenuhi syarat 7 rumah atau $7,8 \%$, sedangkan yan tidak memenuhi syarat 83 rumah atau $92,2 \%$.

Hasil penelitian menunjukkan bahwa mayoritas rumah responden memiliki tingkat kepadatan yang tidak memenuhi syarat, yaitu $9 \mathrm{~m}^{2}$ /orang. Jadi, tingkat kepadatan penghuni relatif tinggi, atau dengan kata lain kondisi rumah responden secara umum memiliki kepadatan yang tidak memenuhi syarat. Penulis juga menjumpai, dalam satu rumah ada kalanya dihuni oleh lebih dari $1 \mathrm{kk}$, misalnya jika ada anak yang sudah menikah tetapi masih tinggal serumah dengan orang tuanya. Hal ini khususnya dijumpai pada responden yang jumlah penghuni rumahnya di atas 5 orang.

Kepadatan hunian rumah akan meningkatkan suhu ruangan yang disebabkan oleh pengeluaran panas badan yang akan meningkatkan kelembaban akibat dari uap air dari pernapasan tersebut. Dengan banyaknya penghuni maka kadar oksigen dalam ruangan menurun dan diikuti oleh peningkatan $\mathrm{CO}^{2}$, akan berdampak meningkatnya kondisi kelembaban udara karena kandungan uap air dalam ruangan meningkat. Menurut Benyamin Lakitan (1994 h.147) sesungguhnya angin mempunyai fungsi lain yang sangat penting adalah 
dalam mencampur lapisan udara, antara udara lembab dengan udara kering, antara udara yang kaya karbon dioksida (CO2) dengan udara dengan kandungan karbon dioksida (CO2) yang lebih rendah. Kepadatan hunian akan meningkatkan kelembaban akibat dari uap air dari pernapasan .

Hasil analisis statistik menunjukkan bahwa hubungan antara kepadatan penghuni dengan kelembaban dinyatakan tidak signifikan karena nlai $p$ value lebih besar dari 0,05 yaitu 0,239 untuk

hubungan dengan kelembaban. Kekuatan hubungannya juga lemah, yaitu 0,151 untuk hubungan dengan kelembaban. Hal ini menunjukkan bahwa kepadatan penghuni tidak memberikan dampak yang berarti terhadap kelembaban pada rumah responden.

\section{Kesimpulan}

\section{Simpulan}

Kondisi suhu pada ruang keluarga responden yang memenuhi syarat 62 rumah atau $69,8 \%$, yang tidak memenuhi syarat 28 rumah atau $31,1 \%$.

Kondisi kelembaban pada ruang keluarga responden yang memenuhi syarat sebanyak 49 rumah atau $54,4 \%$, yang tidak memenuhi syarat sebanyak 41 rumah atau $45,67 \%$.

Faktor-faktor yang berhubungan dengan kondisi suhu pada ruang keluarga responden adalah jenis lantai dan jenis dinding, sedangkan luas ventilasi, pencahayan dan kepadatan penghuni tidak berhubungan dengan kondisi suhu.

Faktor-faktor yang berhubungan dengan kondisi kelembaban pada ruang keluarga responden adalah jenis lantai, luas ventilasi dan jenis dinding, sedangkan pencahayaan dan kepadatan penghuni tidak berhubungan dengan kondisi kelembaban.

\section{Saran}

Perlu dilakukan penelitian lebih lanjut dengan

variabel dan cakupan tempat penelitian yang

lebih luas.

\section{Ucapan Terima Kasih}

Terima kasih disampaikan kepada pemerintahan dan masyarakat Desa Kotayasa serta Jurusan Kesehatan Lingkungan Politeknik Kesehatan Kemenkes

Semarang, sehingga penelitian ini dapat terselesaikan.

\section{Daftar Pustaka}

Azrul Azwar, 1990, Pengantar Ilmu Kesehatan Lingkungan, Jakarta: Mutiara Sumber Widya

Moeliono, 1990, Kamus Besar Bahasa Indonesia, Jakarta : Departemen Pendidikan dan Kebudayaan, Penerbit : Balai Pustaka

Frick Heinz, 1993, Ilmu Konstruksi Bangunan I, Jakarta: Penerbit Kanisius
Benyamin lakitan, 1994, Dasar-Dasar Klimatologi, Jakarta: Raja Grafindo persada

Nur Achmad Yusup dan Lilis Sulistyorini, 2005, Hubungan Sanitasi Rumah Secara Fisik dengan Kejadian ISPA pada Balita, http://jurnal.unimus.ac.id/index.php/Analis/a rticle/view/298/323, diakses tanggal 10 Pebruari 2016 pukul 19.30 WIB

Tulus Aji Yuwono,2008 , Faktor-Faktor Lingkungan Fisik Rumah yang Berhubungan dengan Kejadian Pneumonia pada Anak Balita di Wilayah Kerja Puskesmas Kawunganten Kabupaten Cilacap, Semarang : Program Pasca Sarjana, Universitas Diponegoro

Vita Ayu Oktaviani, 2009, Hubungan antara Sanitasi Fisik Rumah dengan Kejadian Infeksi Saluran Atas (ISPA) pada Balita di Desa Cepogo Kecamatan Cepogo Kabupaten Boyolali, Surakarta : Program Studi Kesehatan Masyarakat, Fakultas Ilmu Kesehatan, Universitas Muhammadiyah Surakarta

P2KP, 2010, Tentang Rumah Sehat, http://www.pnpmperkotaan.org/.asp? mid=3049\&catid=2\&, diakses tanggal 7 Pebruari 2016 pukul 21.10 WIB

Aris Santjaka, 2011, Statistik untuk Penelitian Kesehatan, Jokjakarta: Nuha Medika , 2011, Aplikasi SPSS untuk Analisa Data penelitian kesehatan, Jokjakarta : Nuha Medika

Depkes RI, 2011, Per Men Kes RI Nomor : 1077/Menkes/Per/V/2011, tentang Pedoman Penyehatan Udara dalam Ruang Rumah, Jakarta: Depkes RI

Ajeng Ritzki Pitakasari, 2012, Perubahan Iklim, Waspadai Penyakit ISPA

http://nasional.republika.co.id/berita/nasional/umum/ diakses tanggal 7 Pebruari 2016 pukul 21.00 WIB

Tri Cahyono, 2014, Pedoman Penulisan Proposal Penelitian dan Karya Tulis Ilmiah/Skripsi (Edisi Revisi Ke Tiga),Purwokerto : Jurusan Kesehatn Lingkungan Purwokerto

Hanifah Shalihah, 2016, Suhu dan Kelembaban, http://besta-indonesia.academia.edu/, diakses tanggal 7 Pebruari 2016 pukul 21.30 WIB

Tika Nurlaylilatifah, 2016, Teori Ultraviolet, http://www.academia.edu/9950096, diakses tanggal 10 Pebruari 2016 pukul 19.10 WIB 